\title{
The Geological Society of Africa role and objectives for the 21st century
}

\begin{abstract}
The Geological Society of Africa (GSA) was founded in 1973 with two main objectives: to promote the understanding of earth science in the African continent, and to assist the newly independent African states in the acquisition of well-trained manpower for the exploitation and management of the enormous mineral wealth of this continent. The Society has registered some achievements and disappointments insofar as addressing its founding objectives are concerned. As the new century approaches, the Society realises the importance of being more service-oriented than hitherto. Hence, the Society's main activities in the new century will be centred on water, mineral raw materials, the environment, geohazards, women and earth science education for the socio-economic development of the peoples of the African continent.
\end{abstract}

\section{The historical perspective}

A conference on African geology was held in Ibadan, Nigeria in December 1970 to mark the 10th anniversary of the founding of the Department of Geology at the University of Ibadan. At the end of that conference an ambitious and forward-looking decision was made to establish a Geological Society of Africa. A Steering Committee was set up to draft a suitable constitution, with instructions to report to a second conference of African geology to be held in Addis Ababa (Ethiopia) two years thence.

The Steering Committee met under the Chairmanship of Professor R Black of the Department of Geology, Haile Selassie I University, Addis Ababa in 1971 and drafted a provisional constitution. This was approved at the second conference in December 1973 and the Geological Society of Africa (GSA) was formally established. Professor M O Owawoye of Nigeria was the first President and Dr S M El Rabba, from Sudan, the first Secretary General.

The main objectives of the Society were:

- to promote the understanding of earth sciences in the African continent;

- to provide a forum for discussion and dissemination of information and cooperation between scientists and associations engaged in African geology;

- to promote the development of Africa's earth resources for the benefit of Africa, and

- to assist African National Governments in the acquisition and training of specialised personnel to solve their manpower requirements.

\section{National geological societies}

It is important to note that some national geological socicties and associations were in existence long before the birth of GSA. For example, the geological societies of Egypt and South Africa were both founded in 1895 and are amongst the oldest geological societies of the world. A major early task of the fledgling Society, was to encourage the formation of national societies within the continent, a process that continues to this day, for example in Malawi. Most of the national geological societies in Africa were formed in the period between about 1970 and 1980 , almost parallel with the establishment of the GSA and geological departments and institutes within the then existing African universities. GSA has been instrumental in assisting the establishment of many of these national institutions and seeks to encourage further interaction and affiliation with the Society so as to involve national geoscientists at grassroot level in the development of the geology and mining industry in Africa. These national bodies act as conduits for the transmission of the Society's programmes of action down to the national grassroot geoscientists.

Many of the young nation states in which these societies were established were either known to be well endowed with natural resources or at least suspected to have mineral and/or energy potential on geological grounds. Many of these states inherited a strong base of geological information and had a history of geological investigation and research through the pioneering activities of the geological survey departments during the pre-independence era. The work of the geological surveys continues to the present day and the Society is striving to strengthen its links also with those organisations, to foster its constitutional objectives. It is encouraging, therefore, to note the current resurgence of interest in the role and significance of national geological surveys and related regional organisations such as the Eastern and Southern Africa Mineral Resources Development Centre (ESAMRDC), based in Tanzania, and the Southern African Development Community Minerals Coordination Unit (SADC$\mathrm{MCU}$ ) in Zambia. Strengthening of these institutions is a consequence of the present recognition by the international community of the need for reliable and accessible geoscience information to promote social and economic development in the continent, in keeping with the Society's objectives and aspirations.

\section{Achievements}

The health of the Society has waxed and waned, as societies and institutions do, particularly in the changing times since its foundation in 1973. There have been good and bad times. It has registered achievements and disappointments insofar as addressing its founding objectives are concerned, and it faces problems common to all organisations, and indeed nations, in a continent which has seen considerable and continuing change. The Society, through its grassroot members and affiliated national geoscientific societies and associations, has made much progress especially in the areas of training and institution building: research and mineral resource development.

\section{Training of African geoscientists}

At the time of widespread political independence in Africa (in the early 1960 s), not more than five countries within the whole of the African continent had geoscientific training institutions. Over $95 \%$ of the first generation of indigenous African geoscientists (first degree graduates during the later 1960s and early 1970s) were trained mostly in European and North American universities. Today, almost every African country has at least one institution of higher learning with one or more geoscientific training departments or institutes. 


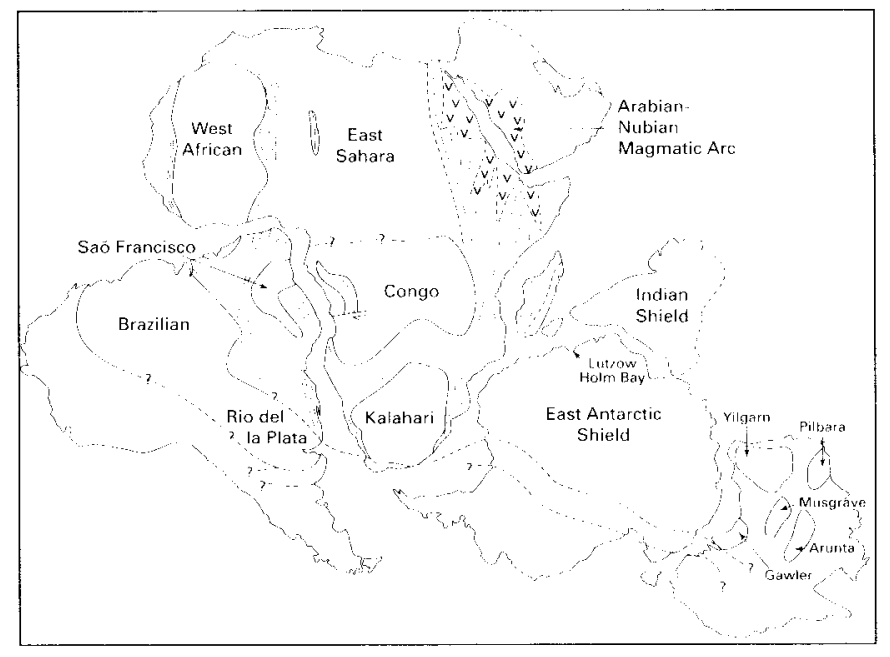

Figure 1 Africa's position in the reconstructed Gondwanaland. Pre-Pan African ( $>900 \mathrm{Ma}$ ) cratons are named; pecked lines represent Pan African mobile belts ( 900-450 Ma). (From Kroener, 1991).

Members of the Society and of local national socicties have been at the forefront of training young African geoscientists for the demands of the future. Today, Africa can proudly claim to have enough qualified manpower in the various fields of earth sciences. However, credit should be given to the many foreign countries, notably the UK, France, Germany, Belgium, the former USSR, Nordic countries, Canada, Australia and USA for training the indigenous African geoscientists overseas, particularly in more recent years at the postgraduate level. These countries, and multilateral donors such as the UN and the development banks, also provided, and continue to provide, experts, finance and materials for the estahlishment and running of most of the geoscientific national institutions in Africa, especially in the period between 1960 and 1985. The downside to this achievement is that some countries, such as Nigeria. Ghana and Egypt have long lists of jobless geoscientists. A country like Tanzania with only one department of geology (founded in 1974) within her three universities, today, has a total of about 400 BSc and 20 PhD graduates in geological sciences.

Some countries have made one leap forward by coming together and establishing regional institutions dealing with mineral resources development for their own countries. The well-equipped Eastern and Southern African Mineral Resources Development Centre (ESAMRDC) based in Dar-es-Salaam, Tanzania, is an example worth mentioning. This centre is an intergovernmental organisation built on a cooperative basis for providing technical, consultancy, laboratory, training and other specialised services for mineral resources development to all countries in this part of the continent. SADC through its Minerals Coordination Unit (in Lusaka, Zambia) offers another example of regional cooperation within the continent.

Earth science subjects, e.g. geomorphology, physical geology, geophysics, oceanography and environment are now forming part of school curricula in Africa. The Geological Society of Africa and its affiliated national societies organises international and local conferences, seminars and training workshops throughout the continent. These meetings act as channels for the dissemination of geoscientific knowledge in Africa. The Society is continuously attempting to create awareness among the public and decision-makers on issues such as mineral economics and environmental degradation in Africa.

\section{Research in earth sciences}

Africa was the last continent to become involved in the training of her own experts in earth science. At the time when Alfred Wegener (1912) was propounding his continental drift theorem, the whole of Africa was overlain by colonialism. South Africa was the only country where earth science was evolving with rhythms similar to those in Europe and North America. At the time Alex Du Toit (1937) was publishing his book Our Wandering Continents, there was no black gcologist in that country. Hence, South Africa is not truly representative of the rest of Africa. When the 18 th International Geological Congress was held in London in 1948 and Arthur Holmes (1951) surprised the majority of the participants by claiming that the highgrade Mozambique orogenic belt of eastern Africa was younger than the low-grade Tanzania-Congo craton (a big contradiction to the then-popular geosynclinal theory), Africa, with the exception of Egypt and South Africa, had only few secondary-school educated indigenous Africans employed as field assistants and laboratory attendants in the colonial geological surveys. Nor did African geoscientists take any active part in the discussion and formulation of the sea-floor spreading concept in the carly 1960s. Africa was indeed very late in joining other continents in the study of our planet and its mineral resources. A tremendous job has been done subsequently by African national governments, their institutions and professional societies to make sure that this anomaly is eradicated.

The geology of Africa is very fascinating. Reconstructions of Pangaea and Gondwanaland are incomplete without the African continent (Figure 1). We can exemplify this assertion by considering the well-known mineral-rich ancient terrains of Africa. The area of exposed Archacan crust makes up $22 \%$ of the Earth's total exposed Precambrian crust, and of this amount, Africal alone accounts for $32 \%$ (Goodwin, 1991). The same author has reported that Africa accounts for about $30 \%$ and $12 \%$ of the total exposed Palaeoproterozoic and Mesoproterozoic crusts, respectively. The exposed Neoprotero\%oic crust makes up $33.5 \%$ of the Earth's total exposed Precambrian crust and of this Africa accounts for 56.4\% (Goodwin, 1991). Thus, Africa with its magnificent geology is indeed a huge laboratory in which abundant data can be collected for increasing our knowledge of geological processes and concepts, and for the better understanding of the geodynamic evolution of our planet.

Many international journals are today publishing high-quality research papers from members of the Geological Society of Africa. Each national geoscientific society in Africa aims at having one journal or bulletin for the publication of its conference proceedings and research papers. At the moment, there are two international journals (Journal of African Earth Sciences and Africa (ieoscience Review) which are devoted to the geology and mineral resources development of Africa. The Society has also resuscitated its newsletter Africa Geonews, to help develop and maintain contact between its disparate membership.

\section{Mineral resource development}

Africa is endowed with a variety of minerals which are of great significance to the socio-economic development of mankind. Table 1 shows the African production of certain minerals to the world market at approximately the time when the Geological Society of Africa was being founded.

Africa has a wide spectrum of tectonic settings in which there are energy sources and mineral deposits of all kinds. An east-west geological section through the African plate passes from the IndianCarlsberg ridge through Phanerozoic basins and domes, Rift sys-

Table I African mineral production (from Clifford, 1971).

Commodity $\begin{gathered}\text { Percentage of } \\ \text { World production }\end{gathered}$

\begin{tabular}{lr}
\hline Asbestos & 20 \\
Chromite & 44 \\
Cobalt & 73 \\
Copper & 27 \\
Diamond & 94 \\
Gold & 69 \\
lron ore & 4 \\
Lead & 3 \\
Tin & 13 \\
Zinc & 3
\end{tabular}


tems, Precambrian basins and fold belts to the Mid-Atlantic ridge which marks its western boundary.

All these geological features are important sites for metalliferous and non-metalliferous mineral deposits, gemstones, hydrocarbons and geothermal energy. However, African minerals have been plundered since the 14th century, beginning with sailors from Portugal, Turkey and the Arab countries. The developed countries, through their exploration and mining companies continue, unabated, to rob the African continent of its mineral wealth but this is a digression beyond the scope of this article.

The Geological Society of Africa was not only conceived for academic purposes. African earth scientists are equally concerned about mineral resource development and with improving the socioeconomic benefits brought by the mining sector. Africa is still the leading cheap producer of many valuable minerals but unfortunately, has not as yet benefited fully from her enormous mineral wealth. The non-mechanised and weather-dependent agricultural system of Africa has also failed to bring about positive socio-economic development, especially in the rural areas where over $80 \%$ of the African population live. Africa has also to undergo an "industrial revolution' if it really wants to build up a continent-wide affluent society and, at the same time, catch up with the technological advancement of other continents. However, the politics of the world marketing system are also beyond the scope of this article. The Society continues to urge exploration and mining companies operating in Africa to support its endeavours in these areas by taking out corporate memberships, to help further foster training and permit increased GSA sponsorship and support of projects. There remains much to be done and the Society is confident that it can assist this process in its own small way.

\section{Prevailing problems of the Society}

Since the Society is made up of individual and institutional members, it is obvious that the major problems facing the Society are, 10 a greater extent, similar to those facing its members. The African economy is in a mess and it seems that almost all political leaders and decision-makers have failed to define the right priorities and strategies for the socio-economic and technological development of our continent. African earth scientists recognise the important role which mineral resources can play in the alleviation of poverty in our continent and are aware of the growing demand for minerals and fossil fuels needed by the growing industrial sector in the continent. However, there remains an unfortunate tendency among many national governments to fail to utilise local or regional African materials. The institutions in which these geoscientists work are poor in resources. The question to ask ourselves is, 'when and how will the majority of the African earth scientists gain real scientific and professional experience?

\section{Lack of support from the national governments}

The first (1973-76) and subsequent Councils of the Geological Society of Africa emphasised the importance of protecting the integrity of the Society by enabling it to be as financially independent of funds from outside the continent as possible and it specially requested the understanding of the African national governments in this regard. The unfortunate present situation is that very few governments give adequate financial, material and moral support to their national societies or to the Geological Society of Africa to enable them address the constraints on development at the local level, be it utilising local sources of industrial minerals or providing groundwater at a somewhat more sophisticated level. Such assistance would initiate a sense of dynamism and purpose, and encourage result-oriented national geoscientific societies throughout the continent. The Geological Society of Africa has urged, and is continuing to urge. African national governments to support it and its national sister societies by taking out institutional (corporate) membership in the Society through their geological surveys, universities, national science councils or academies of sciences.

\section{Lack of support from the OAU and ECA}

There has been similar lack of support, since the birth of the GSA. from the Organisation of African Unity (OAU) and the Economic Commission of Africa (ECA). From the outset the Society had agreed that these two powerful economic and political continental bodies should be requested to recognise the Geological Socicty of Africa as the main professional society for geosciences in Africa, able to distance itself from national issues and priorities, so being able to play a part in the development of geological sciences and the mining industry in the continent. It was further agreed that the Secretariats of these two organisations be requested to support and assist in acquiring recognition and material support from $A$ frican national governments. It is unfortunate that, so far, neither the OAU nor the ECA have offered anything.

In summary, the main problems facing the Geological Society of Africa and its fellow national societies, are:

- lack of funds, especially to support grassroot and institutional members in running professional programmes:

- limited moral and material support from the majority of the employers of our grassroot members:

- poor communication infrastructure within Africal which hinders the smooth and rapid dissemination of information within the continent:

- politicians and decision-makers who lack the will to work together with their own local experts. Science and technology now features on political agenda in Africa but serious consideration has yet to be given to implementation and action on the pronounced policies;

- lack of convertible currencics: and

- lack of permanent office premises.

\section{The future role of the Society}

The geological sciences, like other branches of science, are dynamic and constantly changing in response to new scientific and technological discoveries and to the practical needs of living communities. In realistic terms, the African cconomy is stagnant and is characterised by, "despair and migration of energetic youth from the dominantly peasant rural areas to the urban industrial and trading centres'. Poverty is indeed penetrating Africa hither and thither. Our continent has an average population growth rate of about $3.5 \%$ per annum and in the world as a whole, 100 million people are added each year. Hence, the supply of essentials (water, food, shelter, clothing, fuel and mineral raw materials) will have to increase at more or less the same rate as our population growth-- but some of these essentials are non-renewable. All this compels our national, continental and global professional bodies to be more service-oriented than previously anticipated.

The Geological Society of Africa has formulated the following key objectives as the new century approaches:

- the provision of water for all in Africa:

- the adoption of environmentally sensitive practices in the development and management of fossil fuels and mineral resources for the socio-economic benefit of the continent:

- the encouragement of African women in the geosciences:

- improving standards in earth science education and research in Africa, and significantly enhancing contributions to the study of geological processes and behaviour, not only in Africa but of the whole earth system; and

- improving the forecasting, mitigation and averting of geoba\%ards and natural disasters, environmental degradation and health problems associated with geological processes within Africa. 


\section{Research priorities}

The above key objectives reflect the current broad span of chronic socio-economic problems that face the African countries today. The Society aims to promote work and training to address these key objectives and, to this end, has identified six priority areas of research:

- water resources:

- fossil fuel resources;

- metallic and non-metallic deposits;

- carth science education:

- palaeoenvironments and environmental degradation; and

- geological hazards.

Water is essential to all living things, yet over $70 \%$ of the African population has neither clean drinking water nor enough water for agricultural and other developmental purposes. With the average population growth rate of $3.5 \%$ in the continent, there is an increasing demand for water in both the rural and urban areas. The Society, through its grassroot members, will explore for more water resources, especially the groundwater deposits which are claimed to be abundant within the first 200 metres of the African crust. Water quality and management; and water as a source of energy (hydroelectric power. geothermal energy), are other subjects of major interest to the Society.

Fossil fuel is the backbone of all industrial enterprises and a necessity for modem civilisation. Coal is abundant in Africa, yet the common man in this continent continues to be dependent on firewood and charcoal for domestic purposes. GSA intends to spearhead research into the exploration and estimation of the quantity and quality of coal deposits in Africa. The number of hydrocarbon discoveries in Africa is gradually increasing. So far, Africa has been very fortunate in striking large gas fields, e.g. gas from the Lower Cretaceous sands of the Songo Songo Island in the Indian Ocean (about $200 \mathrm{~km}$ south of Dar-es-Salaam. Tanzania) tested up to 23 million cubic feet per day of gas. Resources on this scale may, subject to favourable economic and political conditions, have potential as an alternative source of energy and for the production of chemical fertilisers. Despite the existence of favourable geological features for hydrocarbon concentrations, economically viable oil fields are still scarce in Africa. The Society recognises the importance of new discoveries, exploitation and sound management of oil and gas resources in this underdeveloped continent. Proper use of fossil energy will avert deforestation, soil erosion and desertification which are now threatening sustainable habitation on the continent.

Maintaining high standards of living and sustaining large populations in Europe, North America and parts of Asia are only possible through 20th century discoveries and advancement in science and technology, especially in the use of mineral resources in agriculture and industry. An artificial measure for the level of modern development of any society is sometimes given in terms of the tonnage of industrial minerals that a person uses per annum. If such an indicator is valid, then the statistics for the African countries make very dismal reading. The Society puts a high priority on supporting research leading 10 more discoveries of metallic and non-metallic deposits in Africa and into alternative uses and import substitution.

Earth science education in Africa is still in its infancy. Since geological knowledge is important for making decisions on the rate of exploitation and management of water, energy and mineral resources, protection of the environment and aversion of natural disasters, African schools, polytechnics and universities have to accommodate this new earth science subject in their curricula. African women, the prominent societal architects and bread-earners in the rural areas, have to be given special preference and encouragement to take up earth science courses in their tertiary education. This is another area where the Sociely will put much more emphasis.

Environmental degradation in Africa is not yet as bad as in the industrialised continents. However, measures have to be taken now to arrest pollution, deforestation, soil erosion, landslides and desertification which are threatening some parts of the continent. The Society encourages extensive research work in palacoenvironments and on the environmental impact of artisanal, small- and large-scale mining activities in Africa. Of late, Africa has gradually been turning into a 'warehouse' for toxic and radioactive waste from the rich nations or companies. The Geological Sociely of Africa is aware of the serious health hazards which can emanate from such dumping. It addresses itself to this problem with greal concern.

A further task facing the Society in the 21 st century is in helping to prepare for, mitigate, avert and protect the peoples of the continent from, the scourge of natural disasters associated with geological processes operating on and beneath the Earth's surface-hazards such as earthquakes, volcanoes, landslides, floods, devastating winds and subsidence whether natural or man-made (e.g. mining). Dissemination of knowledge on these geological hazards and of means of addressing them by the involvement of the general public merit the Society's attention.

\section{New organisation of the Society}

The Geological Society of Africa has an important role to play in the economic growth and alleviation of poverty within the African continent. The new ambitions in the new 21 st century can be achieved

Table 2 The Council of the Geological Society of Africa.

Office Present incumbent

Address

Department of Geology, University of Dar-es-Salaam. PO Box 35052, Dar-es-Salaam, Tanzania Phone: (+255-51) 43638/43500-8: fax: $(+255-51) 43380 / 43078$ e-mail: muhongo@udsm.ac.t7.

Secretary General Dr S N Ayonghe

Hon Treasurer Dr J D Bennett

5 Vice Presidents (representing Northern, East, West, Central and Southern Africa)

Assistant Secretary General 5 Councillors Outgoing President Editor
Department of Geology, University of Buea, PO Box 63, Buea, Cameroon. Phone: $(+237)$ 322134; fax: $(+237) 322272$

British Geological Survey, Keyworth, Nottingham NG12 5GG, UK. Phone: (+44-115) 9363224; fax: $(+44-115) 9363474$ e-mail: john.d.bennett@bgs.ac.uk 
through a well-organised and efficient network within its 'core'- the grassroot members. A new plan, detailed on the next page has been adopted for the future running of this continent-wide professional body.

\section{The Constitution of the Society}

The 1973 constitution of the Society was amended in 1990, but more changes are needed, especially on issues such as the election procedure and the term of office of Members of the Council. The Constitution has also to move with, and reflect, our new needs and co-existence in the contemporary world. The current Council will present its recommendations for constitutional changes before the Members' General Assembly at the next conference to be held in 1998 in either Angola or Namibia. The Society is led by a Council serving a threeyear term. The Composition of the Council with the names and addresses of key members is shown in Table 2.

\section{National Chapters}

The Society has selected one active member in each country as its liaison officer in that respective country. National Chapters are in direct contact with the Council of the Society. Their role is to initiate and supervise GSA-supported projects and programmes within their own countries, and to report to the Council at the end of each calendar year. These National Chapters, together with their national working groups, are perceived as chambers from which future top officials of the Society will be elected.

\section{Publications}

Dissemination of the findings of research in all the above-mentioned priority activity areas is an area where the Society can make an important contribution. The standard of publications of the African geoscientists has improved tremendously in the last ten years. The Geological Society of Africa will continue to support individual geoscientists, especially the young ones, in maintaining this encouraging progress and to encourage the national geoscientific bodies to establish or strengthen their own national journals, bulletins and newsletters. The Geological Society of Africa will continue using the Journal of African Earth Sciences and the newly founded Africa Geoscience Review as its 'official' publications. The Society's newsletter, Africa Geonews, has recently been launched. The Geological Society of Africa is determined to make sure that the chronic 20 th century scientific communication problems within Africa is reduced to a minimum.

\section{International collaboration}

The Geological Society of Africa recognises that it, too, has a contribution to make to, and responsibilities in the wider global geoscientific framework. It has long-term traditional working allies: UNESCO, IUGS and IGCP and other international geoscientific bodies. The Society will continue working very closely with these bodies. The Society intends, by the year 2005 , to increase by $20 \%$ the number of African-led research projects within the International Geological Correlation Programme (IGCP) and the International Lithosphere Programme (ILP). The Society, through its Council and grassroot members, intends to be active in developing project ideas in-line with the above described philosophy and to assist this process by making available funds from its own limited resources and securing support from international agencies, including those mentioned above, within and outside the continent.

The Geological Society of Africa (GSA) invites individuals, companies and other earth science professional bodies to collaborate with their fellow African earth scientists in studying the unique natural heritage of the continent: geological terrains of all ages, geological structures of all kinds, exotic and precious minerals of all kinds and a home of human ancestors. There is always something new in Africa-where else can be found such an accumulation of Earth's fascinations?

\section{References}

Clifford, T N , 1971, Location of mineral deposits, in Gass, I G, Smith, P J and Wilson, R C L, eds., Understanding the Earth: Open University Press, pp.315-325.

Du Toit, A L, 1937, Our wandering continents: Oliver and Boyd, London, $366 \mathrm{pp}$.

Goodwin, A M, 1991, Precambrian geology: The dynamic evolution of the continental crust: Academic Press, N Y, $666 \mathrm{pp}$.

Holmes, A C, 1951, The sequence of Precambrian orogenic belts in south and central Africa: Proceedings of the 28th IGC, London, 14, pp.254-269.

Kroener, A, 1991, African linkage of Precambrian Sri Lanka, Geologische Rundschau, v. 80, no. 2, pp.429-440.

Wegener, A, 1912, Die Entstehung der Kontinente: Geologische Rundschau. v. 3, pp. $267-292$.

Wilson, J.T, 1963, Continental drift: Scientific American, v. 208, pp.86-100.

Professor Sospeter Muhongo is the current President of the Geological Society of Africa. Born in Tanzania in 1954, he graduated from the University of Dar-es-Salaam in 1979 before moving to the Universities of Göttingen and the Technical University of Berlin Germany, for postgraduate studies. His major research interest is in the tectonics, structural geology and mineralisation of Precambrian metamorphic terranes. He is the leader of IGCP project 348: The Mozambique and Related Orogens.

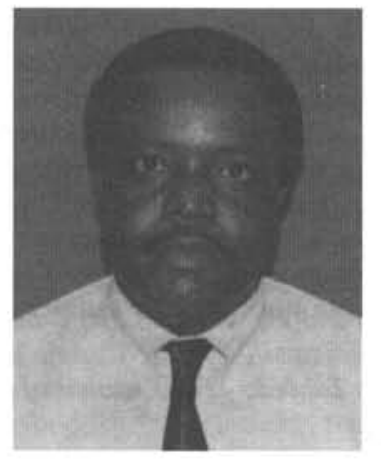

